\title{
Genomic and post-genomic analyses of human prion diseases
} Maurizio Pocchiari* ${ }^{* \dagger}$, Anna Poleggi*, Serena Principe*, Silvia Graziano*+ and Franco Cardone*

\begin{abstract}
Addresses: *Department of Cell Biology and Neurosciences, Istituto Superiore di Sanità, Viale Regina Elena 299, o0161 Rome, Italy. ${ }^{\dagger}$ CEA,Institute of Emerging Diseases and Innovative Therapies, SEPIA, F-92265 Fontenay-aux-Roses, France.
\end{abstract}

Correspondence: Maurizio Pocchiari. Email: maurizio.pocchiari@iss.it

Published: 22 June 2009

Genome Medicine 2009, I:63 (doi:10.1 186/gm63)

The electronic version of this article is the complete one and can be found online at http://genomemedicine.com/content///6/63

(C) 2009 BioMed Central Ltd

\begin{abstract}
Prion diseases share common features of neurodegenerative disorders, infectious diseases and pathologies linked to misfolded proteins. Whether these aspects are independently and fortuitously present in prion diseases or are somewhat linked together remains unsettled, but the contribution of genomic, proteomic, metabolomic and spectroscopic techniques might give insights into this puzzle, and likely give hope for therapy to patients. Although the prion protein gene (PRNP) governs most of the clinical and pathological features of prion diseases and plays a pivotal role in determining host susceptibility, there are still many uncertainties and unknown risk factors that need to be clarified and identified. Several genes, other than PRNP, have recently been found to be associated with a risk of developing sporadic or variant Creutzfeldt-Jakob disease, but these novel data have been produced in a relatively small number of patients and controls and, therefore, need further confirmation. The same criticism applies to the identification of the over 20 new cerebrospinal fluid or plasma markers of disease. Some of these markers seem related to the massive brain damage that occurs, rather than being specific to prion infection. Nevertheless, genomic and post-genomic approaches have shown that these techniques are very powerful, and the best way to overcome the scantiness of samples would be to encourage strong collaboration between different centers of excellence in prion diseases. In this review, we describe the most recent and outstanding advances offered by genomics and postgenomics analyses in the field of human prion diseases.
\end{abstract}

\section{Introduction}

Transmissible spongiform encephalopathies (TSEs), or prion diseases, are a group of fatal neurological disorders that affect humans and animals, and for which there is no available therapy [1]. The basic pathogenic mechanism is linked to post-translational changes of the host cellular prion protein $\left(\mathrm{PrP}^{\mathrm{c}}\right)$ into a pathological conformer $\left(\mathrm{PrP} \mathrm{PTE}^{\mathrm{TS}}\right)$ that has a strong tendency to aggregate and form amyloid fibrils [2]. As for the $A \beta$ amyloid present in Alzheimer's disease (AD), it is still unclear whether large aggregates of PrPTSE are more or less toxic to neural cells than small oligomers [3]. In humans, the most common form of disease is sporadic Creutzfeldt-Jakob disease (CJD), which equally affects both females and males of all ages, and of all ethnic groups [4]. Sporadic CJD has an overall mortality rate of approximately 1-2 cases per million people per year, with peak incidence in individuals aged between 60 and 70 years [4]. Approximately 10 to $20 \%$ of CJD cases appear within families $[4,5]$ and these forms are always (apart from very few exceptions, for example $[6,7]$ ) linked to point or insert mutations in the prion protein gene, $P R N P$, suggesting that these disorders are strongly linked to $P R N P$ and that, unlike 
other neurodegenerative disorders such as $\mathrm{AD}$, prion diseases are likely monogenetic. Other rare genetic forms of TSEs are fatal familial insomnia (FFI) and GerstmannSträussler-Scheinker syndrome (GSS). Both sporadic and genetic prion disorders are transmissible to a wide range of laboratory animals (rodents, felines, and non-human primates) by the injection of crude brain homogenates. Depending upon the host, the type of inoculum, and the route of inoculation, the lag period between the time of injection and the development of clinical signs may last for weeks, months or years [8-10]. Around one-third into this asymptomatic period, the host starts producing $\operatorname{PrP}^{\mathrm{TSE}}$ using its own $\mathrm{PrP}^{\mathrm{c}}$ as a substrate. At the end of the incubation period the host develops clinical, behavioral, and neurological signs, and finally dies, usually after a few weeks of disease. However, after prion infection, mice with ablated prion protein gene (knock-out mice) do not produce PrPTSE or clinical signs of disease, confirming the pivotal role of $\mathrm{PrP}^{\mathrm{c}}$ in the pathogenesis of prion disorders [11]. In experimental prion models, treatment with a variety of compounds during the asymptomatic phase of disease delays the formation of $\mathrm{PrP}^{\mathrm{TSE}}$ and the appearance of clinical signs [12]. In some cases, animals do not even develop disease [12]. However, there is virtually no beneficial effect if the treatment is started after the appearance of clinical signs, suggesting that the only possible approach in humans is prevention rather than therapy [13]. Naturally, prion diseases occur also in sheep and goats (scrapie disease), in cattle (bovine spongiform encephalopathy (BSE), and some very rare variants), and in cervids (chronic wasting disease (CWD)) [2]. A BSE epidemic, sustained by feeding cows with infected rendered meat, has produced a serious worldwide economic and health problem. Thousands of cattle have been killed in Europe and elsewhere to further prevent the rise of the epidemic and the possibility that BSE would transmit to humans. Despite these efforts, however, transmission of BSE to humans occurred in the 1990 s and approximately 200 people, mostly in their 20s, died of a novel prion disease (variant CJD) [14]. Patients with variant CJD were probably infected via contaminated food in the late 1980 or orly 1990 s, but it is still unknown how many individuals are currently silently incubating the disease [15]. Occasionally, transmission of prion diseases occurs from man to man via improperly decontaminated surgical instruments, use of biological products taken from cadaveric human tissues [16], blood transfusion, or possibly plasmaderived products (so far these two modes of transmission have occurred only for variant CJD) $[17,18]$.

\section{Genetic analyses in human prion diseases}

In humans, the PRNP gene is the only strong factor that determines both susceptibility and phenotypes of prion diseases. This gene presents several point or insert mutations that are responsible for the appearance of familial forms of prion diseases, and often each specific mutation is associated with a specific clinico-pathological phenotype [19]. The most striking example is the mutation at codon 178 (substitution of the aspartic acid with asparagine), which gives rise to two different prion diseases depending on whether the mutation co-segregates with methionine (FFI) or valine (genetic CJD) in the polymorphic codon 129. On the other hand, there is also evidence that within the same family, mutated carriers either develop different clinical phenotypes [20,21], develop disease at different ages, or do not develop disease at all [5]. These findings suggest that some other factors are involved in determining susceptibility to the disease [22], but no specific genomic studies have so far been conducted to exploit the possible involvement of other genes. The only exception is the finding that in a large kindred of GSS-affected patients with the proline to leucine mutation at codon 102 of the PRNP gene, apolipoprotein E4 (ApoE4) carriers have a delay in the age of onset of approximately 10 years without, however, any influence on the clinico-phenotype of the disease [21]. Whether ApoE4 influences age at onset in other forms of genetic prion diseases remains to be determined.

The methionine/valine polymorphic site of the PRNP gene also influences susceptibility to sporadic, iatrogenic and variant CJD. Approximately 60\% of sporadic and 100\% of variant CJD patients are methionine homozygous, compared to $40 \%$ of Caucasian populations, suggesting that there is a genetic predisposition even in the non-hereditary forms of prion diseases [4]. Sporadic CJD is not a single entity and different subtypes show clinical and neuropathological features [19]; some of them, such as disease survival, are partially determined by the polymorphic codon 129 but other factors might be involved in determining the rate of susceptibility, the age of onset, the clinical manifestations and, finally, disease duration [23]. Epidemiological and case-control studies have failed to identify convincing risk factors [24,25] and though it is still theoretically possible that as-yet unidentified environmental events may contribute to the development of the disease, it is likely that other genes are involved in its pathogenesis.

\section{Genomic findings in human prion diseases}

The major host player in controlling susceptibility to prion diseases is the PRNP gene. This was clearly shown in the pre-prion era by the pivotal genetic work carried out by Alan Dickinson and colleagues [26], who called the prion protein gene in mice the sinc gene (after scrapie incubation period) and postulated that other genes would likely be involved in the pathogenesis of experimental scrapie [27]. The involvement of other genes has been subsequently confirmed in different models of scrapie-infected mice [28] but, until recently, there have been no data for human prion diseases. In this respect, an interesting genome-wide study of genetic risk in a human prion disease was recently performed by Mead and colleagues [29] in a relatively large cohort of 
patients with various forms of prion diseases (variant, sporadic, iatrogenic CJD and historical kuru patients [30]) in comparison with healthy British and South Fore (for kuru) people. Genomic DNA was mostly extracted from peripheral blood, though some samples were extracted from brain tissue. The major result of this study is the confirmation that the risk of developing prion diseases is strongly associated with the polymorphic codon 129 of the PRNP gene. The authors also found single nucleotide polymorphisms (SNPs) contributing to disease risk in the intron of $P R N P$, upstream of the gene $R A R B$, which encodes the retinoic acid receptor- $\beta$ protein, and upstream of the gene STMN2, which encodes SCG10/stathmin-like 2, a neuronal growth-associated protein. Genetic risk factors for CJD have previously been identified upstream and downstream of $P R N P[31,32]$, while retinoic acid has been shown to regulate the expression of the prion protein in cell cultures [33], and SCG10 to regulate microtubule stability in neuronal cells, which, in turn, might potentially modulate prion neurotoxicity [34]. It is therefore conceivable that a potential deregulation of $R A R B$ and STMN2 might be involved in the pathogenesis of prion diseases, and hence lead to an increased susceptibility of variant or iatrogenic CJD from exogenous exposure. However, the authors [29] could not link the presence of SNPs in the upstream regions of $R A R B$ and STMN2 to a modification of their expression and, since these genes are not expressed in blood cells, their products cannot be used as possible markers for prion diseases. In two other studies, the same group [35,36] reported two other genes (SPRN and HECTD2) found to be associated with risk of sporadic and variant CJD. SPRN was identified by comparative gene analysis [37]; it encodes Shadoo (Sho, shadow of prion protein), a highly conserved protein that has possible functional links with the prion protein [38], and different genetic variants have been associated with risk for either variant or sporadic CJD [35]. HECTD2 encodes an E3 ubiquitin ligase involved in regulating the incubation time of scrapie-infected mice [36], and a single SNP, located in the intron of the gene, was significantly over-represented in both variant and sporadic CJD [36]. Moreover, a high level of HECTD2 mRNA expression seems to be linked with variant CJD in the UK population [36]. These studies are of great interest but it is somewhat surprising that upregulation of these genes was not found by the same group in their genome-wide association study for the identification of CJD risk-associated factors [29].

In another study, Xiang and colleagues [39] applied global gene expression microarray technology to the frontal cortex of 15 patients with sporadic CJD and compared the global gene expression with frontal cortical samples of patients dying of unrelated diseases without clinical signs of neurological diseases, and with unremarkable neuropathology. They found several upregulated $(n=79)$ and downregulated $(n=275)$ genes in sporadic CJD compared to controls. Some of the upregulated genes are clearly linked to the pathological process of degeneration (for example, those encoding GFAP and $\mathrm{S} 100$; the latter protein is also increased in cerebrospinal fluid (CSF) and plasma of CJD patients), or to the immune and inflammatory responses that clearly occur in prion diseases [40]. The upregulation of genes encoding cysteine-rich intracellular proteins with a high capacity to bind to zinc and copper (that is, metallothionein-1 and -2) has also been previously reported in human prion diseases [41]. Reduced expression was observed in genes (SNAP-25 and synaptophysin) that are involved in synaptic function and plasticity and that were previously found at decreased levels in the cerebral cortex of CJD patients [42]. This work is of great interest in terms of identifying genes that are involved in the pathological process of prion diseases, but it is necessary to validate these results by using control patients with other neurodegenerative disorders, in order to identify prion-specific genes rather than hundreds of genes that are clearly deregulated during massive brain damage.

\section{Proteomics and metabolomics in the search for markers of prion infection}

The only marker that is included in the World Health Organization (WHO) diagnostic criteria for sporadic CJD is 14-3-3 protein in CSF. This marker, alone or in combination with other neuron-specific, brain-derived proteins (neuronspecific enolase, Tau and phosphorylated Tau, and the astrocytic protein S10ob), has been extensively evaluated and validated in all forms of human prion diseases (for comprehensive reports see [43-45]). However, these tests only reach high levels of sensitivity and specificity if a patient is likely, on clinical grounds, to have sporadic CJD [44]; it is thus important to maintain interest in and focus resources on finding novel and more specific markers for prion diseases.

In Table 1, we report novel markers that have been identified in the CSF or plasma of patients with various forms of prion diseases. Data are not always comparable, due to the small number of prion patients and to the choice of controls, often taken from healthy individuals without including patients with different neurodegenerative disorders, rather than being due to the techniques used. These critical aspects were taken into serious consideration by Brechlin and co-workers [46], who applied stringent criteria and appropriate neurological controls for the identification of five possible markers for sporadic CJD using two-dimensional differential gel electrophoresis (2D-DIGE) and matrix-assisted laser desorption ionization (MALDI) mass spectrometry. Interestingly, three of these protein spots were subsequently identified as well-known markers for prion diseases (14-3-3, two spots, and neuronspecific enolase) and the fourth as lactate dehydrogenase, previously reported in sporadic CJD by the same group [47].

The other interesting finding in these studies is that variant and sporadic CJD may present some different biochemical 
Table I

Markers in patients with prion diseases

\begin{tabular}{|c|c|c|c|c|c|}
\hline \multirow[b]{2}{*}{ Marker } & \multirow[b]{2}{*}{ Cellular function } & \multicolumn{2}{|c|}{$\begin{array}{l}\text { Relative levels in human prion } \\
\text { disease compared to controls }\end{array}$} & \multirow[b]{2}{*}{ Reference } & \multirow[b]{2}{*}{ Notes } \\
\hline & & CSF & Plasma & & \\
\hline \multirow[t]{2}{*}{$\alpha \mathrm{I}-\mathrm{ACT}$} & Serine proteinase inhibitor & $\uparrow_{s} C J D$ & $\leftrightarrow \mathrm{sCJD}$ & [54] & $\begin{array}{l}\text { Elevated in urine of } s C J D \text { and in plasma } \\
\text { and CSF of } A D\end{array}$ \\
\hline & & $\uparrow_{s C J D}$ & NT & [63] & \\
\hline$\alpha$-Tocopherol & Major lipophilic antioxidant & $\downarrow_{s} C J D$ & $\leftrightarrow \mathrm{SCJD}$ & [64] & - \\
\hline \multirow[t]{4}{*}{ Apolipoprotein } & $\begin{array}{l}\text { Components of high density } \\
\text { lipoprotein in plasma. Participate in } \\
\text { PrP clustering and sequestration }\end{array}$ & $\leftrightarrow s C J D$ & NT & {$[65]$} & $\begin{array}{l}\text { Over-expression of Apo-J in CJD brains } \\
\text { and in urine of BSE orally-infected cattle }\end{array}$ \\
\hline & & $\begin{array}{l}\text { TrCJD compared } \\
\text { to } s C J D\end{array}$ & NT & [66] & \\
\hline & & $s \mathrm{CJD}(\mathrm{Al}$ and $\mathrm{A} 4)$ & NT & [63] & \\
\hline & $\downarrow_{s} \mathrm{Cl}$ & JD (Apo-J, Clusterin) & NT & [63] & \\
\hline Ascorbate & Major hydrophilic antioxidant & $\downarrow_{s} C J D$ & $\downarrow_{s} C J D$ & {$[64]$} & - \\
\hline C-reactive protein & $\begin{array}{l}\text { Markers for inflammation or tissue } \\
\text { injury }\end{array}$ & NT & $\leftrightarrow s C J D$ & [67] & - \\
\hline \multirow[t]{3}{*}{ Cystatin C } & $\begin{array}{l}\text { A cysteine proteinase inhibitor, } \\
\text { mostly synthesized in the CSF; } \\
\text { it is also localized in glial cells } \\
\text { and neurons }\end{array}$ & $\begin{array}{c}\uparrow C J D \\
\text { (not specified) }\end{array}$ & NT & [68] & $\begin{array}{l}\text { Gene is upregulated in the brain of } S C J D \text {; } \\
\text { reported normal in } A D \text { patients }\end{array}$ \\
\hline & & $\uparrow_{s C J D}$ & NT & [63] & \\
\hline & & $\leftrightarrow \mathrm{sCJD}, \leftrightarrow \mathrm{vCJD}$ & NT & [54] & \\
\hline \multirow[t]{2}{*}{ F2-isoprostanes } & $\begin{array}{l}\text { Markers of lipid peroxidation } \\
\text { and oxidative stress in vivo }\end{array}$ & 个sCJD, $\uparrow_{g C J D}$ & NT & {$[48]$} & - \\
\hline & & $\leftrightarrow \mathrm{vCJD}$ & NT & {$[49]$} & \\
\hline \multirow[t]{2}{*}{ Gelsolin } & Regulator of actin filament assembly & $\downarrow_{\mathrm{S}} \mathrm{CJD}$ & NT & [63] & No difference between CJD and $A D$ \\
\hline & & $\downarrow_{s} C J D$ & NT & {$[46]$} & \\
\hline \multirow[t]{3}{*}{ H-FABP } & $\begin{array}{l}\text { Belonging to a family of small, } \\
\text { highly conserved, cytosolic } \\
\text { proteins involved in fatty acid } \\
\text { transport and metabolism }\end{array}$ & $\uparrow_{s} C J D, \uparrow v C J D$ & $\uparrow s C J D, \uparrow v C J D$ & [55] & $\begin{array}{l}\text { CSF of CJD taken post-mortem while in } \\
\text { controls taken from living individuals; } \\
\text { plasma levels do not differ between CJD } \\
\text { and } A D\end{array}$ \\
\hline & & $\uparrow s \mathrm{sJD}$ & $\uparrow_{s} C J D$ & [56] & \\
\hline & & $\uparrow s C J D$ & NT & [69] & \\
\hline Hp2- $\alpha$ haptoglobin & $\begin{array}{l}\text { Binds hemoglobin for physiological } \\
\text { degradation }\end{array}$ & $\uparrow s C J D$ & NT & [63] & - \\
\hline Interleukin I $\beta$ & $\begin{array}{l}\text { Pro-inflammatory cytokine, } \\
\text { involved in immune response }\end{array}$ & $\uparrow s C J D, \uparrow v C J D$ & NT & {$[70]$} & - \\
\hline Interleukin 4 and 10 & Anti-inflammatory cytokine & $\uparrow_{s C J D}$ & NT & {$[7 I]$} & Not altered in the brain of $\mathrm{sCJD}$ \\
\hline Interleukin 6 & $\begin{array}{l}\text { Markers for inflammation or } \\
\text { tissue injury }\end{array}$ & NT & $\leftrightarrow \mathrm{SCJD}$ & [67] & - \\
\hline Interleukin 8 & $\begin{array}{l}\text { Chemokine with immunoreactive s } \\
\text { propertie }\end{array}$ & $\uparrow s C J D$ & NT & $\begin{array}{l}{[7 I]} \\
\text { CJD }\end{array}$ & Increased in AD, but at a lower level than \\
\hline Lactic acid & End-product of anaerobic glycolysis & $\uparrow_{s} C J D$ & NT & {$[72]$} & Produced by LDH action on pyruvate \\
\hline LDH & $\begin{array}{l}\text { Catalyzes the interconversion } \\
\text { between pyrvate and lactic acid }\end{array}$ & $\uparrow s C J D$ & NT & {$[46,47]$} & - \\
\hline
\end{tabular}




\begin{tabular}{|c|c|c|c|c|c|}
\hline \multirow[b]{2}{*}{ Marker } & \multirow[b]{2}{*}{ Cellular function } & \multicolumn{2}{|c|}{$\begin{array}{l}\text { Relative levels in human prion } \\
\text { disease compared to controls }\end{array}$} & \multirow[b]{2}{*}{ Reference } & \multirow[b]{2}{*}{ Notes } \\
\hline & & CSF & Plasma & & \\
\hline MDA & Marker of oxidative stress & $\leftrightarrow \mathrm{sCJD}$ & $\leftrightarrow s C J D$ (serum) & [73] & $\begin{array}{l}\text { Increased MDA has been reported in } \\
\text { scrapie-infected mice }\end{array}$ \\
\hline \multirow[t]{2}{*}{$\mathrm{PGE}_{2}$} & $\begin{array}{l}\text { Major arachidonic acid metabolite } \\
\text { of the cyclooxygenase pathway }\end{array}$ & $\uparrow_{\mathrm{sCJ}}, \uparrow_{\mathrm{gCJD}}$ & NT & {$[48]$} & $\begin{array}{l}\text { Levels of } \mathrm{PGE}_{2} \text { correlate with disease } \\
\text { duration in } \mathrm{SCJD}\end{array}$ \\
\hline & & $\uparrow v C J D$ & & {$[49]$} & \\
\hline TGF- $\beta 2$ & Anti-inflammatory cytokine & $\downarrow_{s C J D}$ & NT & {$[7 I]$} & $\begin{array}{l}\text { Increased immunoreactivity in neurons of } \\
\text { the neurocortex in } 20 \text { patients with } \\
\text { human prion diseases }\end{array}$ \\
\hline \multirow[t]{2}{*}{ TNF- $\alpha$} & Proinflammatory cytokine & $\uparrow s C J D, \uparrow v C J D$ & NT & {$[70]$} & $\begin{array}{l}\text { Gene is upregulated in the brain of sCJD } \\
\text { patients }\end{array}$ \\
\hline & & ot detectable, sCJD & NT & [7I] & \\
\hline \multirow[t]{2}{*}{ Transferrin } & Iron carrier protein in the blood & $\uparrow s C J D$ & NT & [63] & Upregulated in sera of patients with $A D$ \\
\hline & & $\uparrow s C J D$ & NT & {$[46]$} & \\
\hline Ubiquitin & $\begin{array}{l}\text { Involved in ATP-dependent } \\
\text { selective degradation of cellular } \\
\text { proteins, maintenance of } \\
\text { chromatin structure, regulation } \\
\text { of gene expression, stress } \\
\text { response, and ribosome biogenesis. }\end{array}$ & $\uparrow s C J D$ & NT & [63] & Elevated levels in CSF of AD patients \\
\hline Uric acid & $\begin{array}{l}\text { Non-enzymatic antioxidant } \\
\text { in the brain }\end{array}$ & $\leftrightarrow \mathrm{s} C \mathrm{JD}, \downarrow_{\mathrm{v}} \mathrm{CJ} \mathrm{D}$ & NT & {$[50]$} & $\begin{array}{l}\text { Decreased level in the CSF in } \\
\text { BSE-infected cattle }\end{array}$ \\
\hline
\end{tabular}

Arrows indicate: up, increased; down, decreased; horizontal, equivalent. AI, apolipoprotein I; A4, apolipoprotein 4; $\alpha$ I-ACT, antichymotrypsin; AD, Alzheimer's disease; Apo-J, apolipoprotein J or clusterin; ATP, adenosine triphosphate; BSE, bovine spongiform encephalopathy; gCJD, genetic Creutzfeldt-Jakob disease; sCJD, sporadic Creutzfeldt-Jakob disease; vCJD, variant Creutzfeldt-Jakob disease; CSF, cerebrospinal fluid; H-FABP, heartfatty acid binding protein; LDH, lactate dehydrogenase; MDA, malondialdehyde; NT, not tested; PGE ${ }_{2}$, prostaglandin $\mathrm{E}_{2}$; TGF- $\beta 2$, transforming growth factor- $\beta 2$; TNF- $\alpha$, tumor necrosis factor- $\alpha$.

markers (ApoE [50], F2-isoprostanes [48,49], uric acid [50]; Table 1), which might reflect different molecular processes in these diseases. This observation is in line with what was observed in the recent genomic studies, where different genes or variants of genes are related to one or the other form.

Proteomic approaches have also been extensively used to investigate the pathogenesis of prion diseases, but the majority of these studies, even those conducted with experimental animal models, were performed in postmortem brain tissues, and it is therefore difficult to determine whether deregulation of identified proteins is a late result of neurodegeneration or specifically linked to prionspecific lesions. However, the finding that levels of proteins known to interact with $\mathrm{Ca}^{2+}$, or whose function is regulated by $\mathrm{Ca}^{2+}$, are significantly modified in the brains of affected animals [51-53] clearly deserves further investigation.

By analogy with other neurodegenerative disorders such as $\mathrm{AD}$, the presence of oxidative stress has been investigated in different tissues, including CSF and blood from prionaffected individuals (Table 1 ). These studies have shown the activation of several pro- and anti-oxidative mechanisms in prion disorders, but these pathways are shared by other neurological disorders and cannot be regarded as prionspecific biomarkers. Besides oxidative mechanisms, an atypical inflammatory response is activated in the central nervous system of prion-infected individuals, and consequently a number of (pro)inflammatory mediators are deregulated in the CSF of patients with prion diseases (Table 1) [40]. These mechanisms, however, are often common to other neurodegenerative disorders and may be of limited value as specific prion-disease markers.

Very few studies have been conducted for the identification of markers in human blood or urine [54-57]. Among them, the heart-fatty acid-binding protein (H-FABP) has been found, by two different groups, to be increased in both CSF and plasma of individuals with sporadic and variant CJD $[55,56]$. Blood manganese is another promising marker 
since its concentration is higher in the blood of individuals with sporadic CJD than in patients with other neurodegenerative disorders [57].

\section{Spectroscopic and imaging techniques}

Proton magnetic resonance spectroscopy ( $\left.{ }^{1} \mathrm{H}-\mathrm{MRS}\right)$ has been extensively applied for detecting metabolic alterations in the brain of prion-diseased patients $[58,59]$. These studies, though conducted in a very limited number of patients, are very consistent and always confirm a reduction of $\mathrm{N}$-acetylaspartate (NAA; a marker of neuronal loss), concomitant increase of myo-inositol ( $\mathrm{MI}$; an astrocyte marker), and a reduction of the NAA:creatine ratio. Interestingly, in a single asymptomatic carrier of the pathogenic mutation $\mathrm{P} 102 \mathrm{~L}$ (linked to GSS), Waldman and co-workers found an increase of MI with no variation of NAA [6o], suggesting that gliosis starts before massive neuronal loss, and that this compound may be a valid candidate as a preclinical marker of prion diseases.

The novel technology of atomic dielectric resonance spectroscopy (ADRS [61]) has been demonstrated to discriminate between blood of CJD patients and that of neurological and healthy controls, as well as between sporadic and variant CJD patients, with 100\% specificity and sensitivity. Though these data were blind-validated in only ten patients (four variant CJD, three sporadic CJD, and three non-neurological controls), they confirm data that have been previously reported for the sera of scrapieinfected rodents investigated by Fourier transform-infrared (FT-IR) spectroscopy [62]. It would therefore be interesting to extend the result obtained by Fagge and co-workers [61] to a larger number of patients and possibly to asymptomatic PRNP mutated carriers, to determine whether the ADRS signal might be useful to identify prion disease during the pre- or subclinical phase.

\section{Conclusions}

Sporadic and variant CJD and most of the related prion disorders are relatively easy to diagnose based upon clinical signs and available instrumental and laboratory tools, which include electroencephalography, brain-imaging techniques and detection of the marker $14-3-3$ in the CSF, alone or in combination with other neuron-specific, brain-derived proteins. Thus, in clinical practice the search for other markers in diseased patients is of limited extra value. What is missing, however, is highly predictive markers in easily accessible tissues, such as CSF, blood or urine, that would be able to recognize infected but yet clinically healthy individuals. The best candidate marker would be $\mathrm{PrP}^{\mathrm{TSE}}$, but this pathological isoform is either not present or difficult to identify in body fluids. Markers of prion infectivity are also essential for the screening of blood for transfusion and for plasma or urine donations before their use for production of medicinal products. As a result, resources have been devoted to the development of markers of infection aimed at screening of animal- and human-derived biological products, improving diagnostic tools to identify infected individuals in their preclinical stage of disease, and controlling disease progression. These two latter goals would most likely enhance the possibility of developing preclinical therapy in prion diseases and having objective tools for measuring the effectiveness of potential treatments.

Two other issues in prion diseases that might be solved by the complementary approaches of genomics, proteomics and metabolomics are the search for genes and proteins, other than PRNP and the encoded prion protein, that might increase the susceptibility of developing prion disease. This would apply to the inherited forms of prion diseases, as outlined above, to sporadic CJD, and, of particular importance, to determining why a widespread population exposure to BSE infection has resulted in only approximately 200 cases of variant CJD. Another issue is the identification of genes that influence disease duration. This topic is clearly important for understanding the pathogenesis of prion diseases and might eventually lead to the development of novel anti-prion compounds, but it is also needed in clinical practice to better formulate the prognosis of patients and, finally, to monitor the efficacy of potential drugs in therapeutic trials. The PRNP gene plays an important role in determining survival, as well as the conformational type of $\mathrm{PrP}^{\mathrm{TSE}}$ that accumulates in the brain [23]. However, these factors do not fully explain the great variability observed in human prion diseases and it is therefore likely that other genetic or environmental determinants are involved. Genomic studies are not yet available on this issue, but their application will certainly be of great utility to add other pieces to the prion puzzle.

\section{Abbreviations}

$\mathrm{AD}$, Alzheimer's disease; ADRS, atomic dielectric resonance spectroscopy; ApoE4, apolipoprotein E4; BSE, bovine spongiform encephalopathy; CJD, Creutzfeldt-Jakob disease; CSF, cerebrospinal fluid; CWD, chronic wasting disease; 2DDIGE, two-dimensional differential gel electrophoresis; FFI, fatal familial insomnia; FT-IR, Fourier transform-infrared; GSS, Gerstmann-Sträussler-Scheinker syndrome; H-FABP, heart-fatty acid-binding protein; ${ }^{1} \mathrm{H}-\mathrm{MRS}$, proton magnetic resonance spectroscopy; MALDI, matrix-assisted laser desorption ionization; MI, myo-inositol; NAA, $N$-acetylaspartate; $P R N P$, prion protein gene; $\mathrm{PrP}^{\mathrm{c}}$, cellular prion protein; $\mathrm{PrP}^{\mathrm{TSE}}$, pathological isoform of $\mathrm{PrP}^{\mathrm{c}}$; $\mathrm{SNP}$, single nucleotide polymorphism; TSE, transmissible spongiform encephalopathy; WHO, World Health Organization.

\section{Competing interests}

The authors declare that they have no competing interests. 


\section{Authors' contributions}

All the authors have actively contributed to the preparation of this work.

\section{Acknowledgements}

This work has been partly granted by the EU Specific Targeted project 'Prionscreen' (\#SP5A-CT-2007-044438), by the Italian Ministry of Health 'Progetto Strategico I\%/200I', by the ISS-NIH research program on 'Rare Diseases 2006', and by the ISS grant 'Ricerca Corrente 2006-2008'. Special thanks to $\mathrm{Dr}$ Alessandra Garozzo and Mr Marco Del Re for editorial assistance.

\section{References}

I. Stewart LA, Rydzewska LH, Keogh GF, Knight RS: Systematic review of therapeutic interventions in human prion disease. Neurology 2008 70:1272-1281.

2. Aguzzi A, Sigurdson C, Heikenwaelderw M: Molecular mechanisms of prion pathogenesis. Annu Rev Pathol 2008, 3: I I-40

3. Caughey B, Lansbury PT: Protofibrils, pores, fibrils, and neurodegeneration: separating the responsible protein aggregates from the innocent bystanders. Annu Rev Neurosci 2003, 26:267-298.

4. Ladogana A, Puopolo M, Croes EA, Budka H, Jarius C, Collins S, Klug GM, Sutcliffe T, Giulivi A, Alperovitch A, Delasnerie-Laupretre N Brandel J-P, Poser S, Kretzschmar H, Rietveld I, Mitrova E, de Pedro Cuesta J, Martinez-Martin P, Glatzel M, Aguzzi A, Knight R, Ward H, Pocchiari M, van Duijn CM, Will RG, Zerr I: Mortality from Creutzfeldt-Jakob disease and related disorders in Europe, Australia and Canada. Neurology 2005, 64:| 586-I59I.

5. Ladogana A, Puopolo M, Poleggi A, Almonti S, Mellina V, Equestre M Pocchiari M: High incidence of genetic human transmissible spongiform encephalopathies in Italy. Neurology 2005, 64: I592-I597.

6. Capellari S, Parchi P, Cortelli P, Avoni P, Casadei GP, Bini C, Baruzzi A, Lugaresi E, Pocchiari M, Gambetti P, Montagna P: Sporadic fatal insomnia in a fatal familial insomnia pedigree. Neurology 2008, 70: 884-885.

7. Webb TEF, Pal S, Siddique D, Heaney DC, Linehan JM, Wadsworth JDF, Joiner S, Beck J, Wroe SJ, Stevenson V, Brandner S, Mead S, Collinge J: First report of Creutzfeldt-Jakob disease occurring in 2 siblings unexplained by PRNP mutation. J Neuropathol Exp Neurol 2008 , 67:838-84I.

8. Brown P, Gibbs CJ Jr, Rodgers-Johnson P, Asher DM, Sulima MP Bacote A, Goldfarb LG, Gajdusek DC: Human spongiform encephalopathy: the National Institutes of Health series of 300 cases of experimentally transmitted disease. Ann Neurol I 994, 35:5I 3-529.

9. Tateishi J, Kitamoto T, Hoque MZ, Furukawa H: Experimental trans mission of Creutzfeldt-Jakob disease and related diseases to rodents. Neurology 1996, 46:532-537.

10. Bruce ME, Will RG, Ironside JW, McConnell I, Drummond D, Suttie A, McCardle L, Chree A, Hope J, Birkett C, Cousens S, Fraser H, Bostock CJ: Transmissions to mice indicate that 'new variant' CJD is caused by the BSE agent. Nature 1997, 389:498-50 I.

II. Baron T: Mouse models of prion disease transmission. Trends Mol Med 2002, 8:495-500.

12. Trevitt CR, Collinge J: A systematic review of prion therapeutics in experimental models. Brain 2006, 129:224|-2265.

13. Pocchiari M, Ladogana A, Graziano S, Puopolo M: Creutzfeldt-Jakob disease: hopes for therapy. Eur J Neurol 2008, I5:435-436.

14. Will RG, Ironside JW, Zeidler M, Cousens SN, Estibeiro K, Alperovitch A, Poser S, Pocchiari M, Hofman A, Smith PG: A new variant of Creutzfeldt-Jakob disease in the UK. Lancet 1996, 347:921-925.

15. Pocchiari M: Prevalence of variant CJD in the UK. BMJ 2009, 338: b435.

16. Brown P, Brandel J-P, Preese, M, Sato T: latrogenic Creutzfeldt-Jakob disease. The waning of an era. Neurology 2006, 67:389-393.

17. Turner ML, Ludlam CA: An update on the assessment and management of the risk of transmission of variant Creutzfeldt-Jakob disease by blood and plasma products. Br J Haematol 2009, I44: | 4-23.

18. Eaton L: Haemophilia patient had variant CJD agent in spleen. $B M$ 2009, 338:b705

19. Gambetti P, Kong Q, Zou W, Parchi P, Chen SG: Sporadic and familial CJD: classification and characterisation. Br Med Bull 2003, 66:2 I3239.
20. Barbanti P, Fabbrini G, Salvatore M, Petraroli R, Cardone F, Maras B, Equestre M, Macchi G, Lenzi GL, Pocchiari M: Polymorphism at codon 129 or codon 219 of PRNP and clinical heterogeneity in a previously unreported family with Gerstmann-Sträussler-Scheinker disease (PrP-PIO2L mutation). Neurology 1996, 47:734-74I.

21. Webb TE, Poulter M, Beck J, Uphill J, Adamson G, Campbell T, Linehan J, Powell C, Brandner S, Pal S, Siddique D, Wadsworth JD, Joiner S, Alner K, Petersen C, Hampson S, Rhymes C, Treacy C, Storey E, Geschwind MD, Nemeth AH, Wroe S, Collinge J, Mead S: Phenotypic heterogeneity and genetic modification of PIO2L inherited prion disease in an international series. Brain 2008, |31:26322646.

22. Webb TE, Whittaker J, Collinge J, Mead S: Age of onset and death in inherited prion disease are heritable. Am J Med Genet B Neuropsychiatr Genet 2009, I50B:496-50I.

23. Pocchiari M, Puopolo M, Croes EA, Budka H, Gelpi E, Collins S, Lewis V, Sutcliffe T, Giulivi A, Delasnerie-Laupretre N, Brandel J-P, Alperovitch A, Zerr I, Poser S, Kretzschmar HA, Ladogana A, Rietvald I, Mitrova E, Martinez-Martin P, de Pedro-Cuesta J, Glatzel M, Aguzzi A, Cooper S, Mackenzie J, van Duijn CM, Will RG: Predictors of survival in sporadic Creutzfeldt-Jakob disease and other human transmissible spongiform encephalopathies. Brain 2004, I27: 23482359.

24. van Duijn CM, Delasnerie-Lauprêtre N, Masullo C, Zerr I, de Silva R, Wientjens DP, Brandel JP, Weber T, Bonavita V, Zeidler M, Alpérovitch A, Poser S, Granieri E, Hofman A, Will RG: Casecontrol study of risk factors of Creutzfeldt-Jakob disease in Europe during 1993-95. European Union (EU) Collaborative Study Group of Creutzfeldt-Jakob disease (CJD). Lancet 1998, 35I: I08I-I085.

25. Ward HJ, Everington D, Cousens SN, Smith-Bathgate B, Gillies M Murray K, Knight RS, Smith PG, Will RG: Risk factors for sporadic Creutzfeldt-Jakob disease. Ann Neurol 2008, 63:347-354.

26. Dickinson AG, Meikle VMH, Fraser $\mathrm{H}$ : Identification of a gene which controls the incubation period of some strains of scrapie agent in mice. J Comp Pathol 1968, 78:293-299.

27. Outram GW: The pathogenesis of scrapie in mice. In Slow Virus Diseases of Animals and Man. Edited by Kimberlin RH. Amsterdam: North-Holland Publishing Company; 1976:325-357.

28. Moreno CR, Lantier F, Lantier I, Sarradin P, Elsen JM: Detection of new quantitative trait Loci for susceptibility to transmissible spongiform encephalopathies in mice. Genetics 2003, |65:2085-209|.

29. Mead S, Poulter M, Uphill J, Beck J, Whitfield J, Webb TE, Campbell T, Adamson G, Deriziotis P, Tabrizi SJ, Hummerich H, Verzilli C, Alpers MP, Whittaker JC, Collinge J: Genetic risk factors for variant Creutzfeldt-Jakob disease: a genome-wide association study. Lancet Neurol 2009, 8:57-66

30. Alpers MP: Review. The epidemiology of kuru: monitoring the epidemic from its peak to its end. Philos Trans $R$ Soc Lond B Biol Sci 2008, 363:3707-37I3.

31. Mead S, Mahal SP, Beck J, Campbell T, Farrall M, Fisher E, Collinge J: Sporadic - but not variant - Creutzfeldt-Jakob disease is associated with polymorphisms upstream of PRNP exon I. Am J Hum Genet 2001, 69:1225-I235

32. Vollmert $C$, Wind $O$, Xiang W, Rosenberger A, Zerr I, Wichmann HE, Bickeböller H, Illig T; KORA group, Kretzschmar HA: Significant association of a MI29V independent polymorphism in the 5' UTR of the PRNP gene with sporadic Creutzfeldt-Jakob disease in a large German case-control study. J Med Genet 2006, 43:e53.

33. Rybner C, Hillion J, Sahraoui T, Lanotte M, Botti J: All-trans retinoic acid down-regulates prion protein expression independently of granulocyte maturation. Leukemia 2002, 16:940-948.

34. Kristiansen M, Messenger MJ, Klöhn PC, Brandner S, Wadsworth JD, Collinge J, Tabrizi SJ: Disease-related prion protein forms aggresomes in neuronal cells leading to caspase activation and apoptosis. Biol Chem 2005, 280:3885I-3886I.

35. Beck JA, Campbell TA, Adamson G, Poulter M, Uphill JB, Molou E, Collinge J, Mead S: Association of a null allele of SPRN with variant Creutzfeldt-Jakob disease. J Med Genet 2008, 45:8I 3-8I7.

36. Lloyd SE, Maytham EG, Pota H, Grizenkova J, Molou E, Uphill J, Hummerich H, Whitfield J, Alpers MP, Mead S, Collinge J: HECTD2 is associated with susceptibility to mouse and human prion disease. PLoS Genet 2009, 5:el 000383.

37. Premzl M, Sangiorgio L, Strumbo B, Marshall Graves JA, Simonic T, Gready JE: Shadoo, a new protein highly conserved from fish to mammals and with similarity to prion protein. Gene 2003, 314:89. 102. 
38. Watts JC, Drisaldi B, Ng V, Yang J, Strome B, Horne P, Sy MS, Yoong L, Young R, Mastrangelo P, Bergeron C, Fraser PE, Carlson GA, Mount HT, Schmitt-Ulms G, Westaway D: The CNS glycoprotein Shadoo has PrP (C)-like protective properties and displays reduced levels in prion infections. EMBO J 2007, 26:4038-4050.

39. Xiang W, Wind O, Westner IM, Neumann M, Zerr I, Lederer RM, Kretzschmar HA: Cerebral gene expression profiles in sporadic Creutzfeldt-Jakob disease. Ann Neurol 2005, 58:242-257.

40. Minghetti L, Pocchiari M: Cyclooxygenase-2, prostaglandin e(2), and microglial activation in prion diseases. Int Rev Neurobiol 2007, 82:265-275.

4I. Kawashima T, Doh-ura K, Torisu M, Uchida Y, Furuta A, Iwaki T: Differential expression of metallothioneins in human prion diseases. Dement Geriatr Cogn Disord 2000, 1 1:251-262.

42. Ferrer I, Rivera R, Blanco R, Martí E: Expression of proteins linked to exocytosis and neurotransmission in patients with Creutzfeldt-Jakob disease. Neurobiol Dis 1999, 6:92-100.

43. Sanchez-Juan P, Green A, Ladogana A, Cuadrado-Corrales N, Sáanchez-Valle R, Mitrováa E, Stoeck K, Sklaviadis T, Kulczycki J, Hess K, Bodemer M, Slivarichová D, Saiz A, Calero M, Ingrosso L, Knight R, Janssens AC, van Duijn CM, Zerr I: CSF tests in the differential diagnosis of Creutzfeldt-Jakob disease. Neurology 2006, 67:637-643.

44. Pennington C, Chohan G, Mackenzie J, Andrews M, Will R, Knight R, Green A: The role of cerebrospinal fluid proteins as early diagnostic markers for sporadic Creutzfeldt-Jakob disease. Neurosci Lett 2009, 455:56-59.

45. Ladogana A, Sanchez-Juan P, Mitrová E, Green A, Cuadrado-Corrales N, Sánchez-Valle R, Koscova S, Aguzzi A, Sklaviadis T, Kulczycki J, Gawinecka J, Saiz A, Calero M, van Duijn CM, Pocchiari M, Knight R, Zerr I: Cerebrospinal fluid biomarkers in human genetic transmissible spongiform encephalopathies. J Neurol 2009. doi: 10.1007/s00415-009-5163-x.

46. Brechlin P, Jahn O, Steinacker P, Cepek L, Kratzin H, Lehnert S, Jesse S, Mollenhauer B, Kretzschmar HA, Wiltfang J, Otto M: Cerebrospinal fluid-optimized two-dimensional difference gel electrophoresis (2-D DIGE) facilitates the differential diagnosis of Creutzfeldt-Jakob disease. Proteomics 2008, 8:4357-4366.

47. Schmidt H, Otto M, Niedmann P, Cepek L, Schröter A, Kretzschmar HA, Poser S: CSF lactate dehydrogenase activity in patients with Creutzfeldt-Jakob disease exceeds that in other dementias. Dement Geriatr Cogn Disord 2004, 17:204-206.

48. Minghetti L, Greco A, Cardone F, Puopolo M, Ladogana A, Almonti S, Cunningham C, Perry VH, Pocchiari M, Levi G: Increased brain synthesis of prostaglandin E2 and F2-isoprostane in human and experimental transmissible spongiform encephalopathies. I Neuropathol Exp Neurol 2000, 59:866-87।

49. Minghetti L, Cardone F, Greco A, Puopolo M, Levi G, Green AJ Knight R, Pocchiari M: Increased CSF levels of prostaglandin $E(2)$ in variant Creutzfeldt-Jakob disease. Neurology 2002, 58: I 27-I 29.

50. Lekishvili T, Sassoon J, Thompsett AR, Green A, Ironside JW, Brown DR: BSE and vCJD cause disturbance to uric acid levels. Exp Neurol 2004, 190:233-244.

5I. Giorgi A, Di Francesco L, Principe S, Mignogna G, Sennel L, Mancone C, Alonzi T, Sbriccoli M, De Pascalis A, Rappsilber J, Cardone F, Pocchiari M, Maras B, Schininà ME: Proteomic profiling of PrP27-30enriched preparations extracted from the brain of hamsters with experimental scrapie. Proteomics in press.

52. Jang B, Kim E, Choi JK, Jin JK, Kim JI, Ishigami A, Maruyama N, Carp RI, Kim YS, Choi EK: Accumulation of citrullinated proteins by upregulated peptidylarginine deiminase 2 in brains of scrapie-infected mice: a possible role in pathogenesis. Am J Pathol 2008, I73: I I29I 42.

53. Biasini E, Massignan T, Fioriti L, Rossi V, Dossena S, Salmona M, Forloni G, Bonetto V, Chiesa R: Analysis of the cerebellar proteome in a transgenic mouse model of inherited prion disease reveals preclinical alteration of calcineurin activity. Proteomics 2006, 6:28232834.

54. Miele G, Seeger H, Marino D, Eberhard R, Heikenwalder M, Stoeck K, Basagni M, Knight R, Green A, Chianini F, Wüthrich RP, Hock C, Zerr I, Aguzzi A: Urinary alpha I-antichymotrypsin: a biomarker of prion infection. PLOS ONE 2008, 3:e3870.

55. Guillaume E, Zimmermann C, Burkhard PR, Hochstrasser DF, Sanchez JC: A potential cerebrospinal fluid and plasmatic marker for the diagnosis of Creutzfeldt-Jakob disease. Proteomics 2003, 3:14951499.
56. Steinacker P, Mollenhauer B, Bibl M, Cepek L, Esselmann H, Brechlin P, Lewczuk P, Poser S, Kretzschmar HA, Wiltfang J, Trenkwalder C, Otto $\mathrm{M}$ : Heart fatty acid binding protein as a potential diagnostic marker for neurodegenerative diseases. Neurosci Lett 2004, 370:3639.

57. Hesketh S, Sassoon J, Knight R, Brown DR: Elevated manganese levels in blood and CNS in human prion disease. Mol Cell Neurosci 2008, 37:590-598.

58. Cordery RJ, MacManus D, Godbolt A, Rossor MN, Waldman AD: Short TE quantitative proton magnetic resonance spectroscopy in variant Creutzfeldt-Jakob disease. Eur Radiol 2006, 16:1692-1698.

59. Sarac H, Hajnsek S, Basic S, Henigsberg N, Rados M, Simic G: Magnetic resonance spectroscopy and measurement of tau epitopes of autopsy proven sporadic Creutzfeldt-Jakob disease in a patient with non-specific initial EEG, MRI and negative 14-3-3 immunoblot. Coll Antropol 2008, 32(Suppl I): 199-204.

60. Waldman AD, Cordery RJ, MacManus DG, Godbolt A, Collinge J, Rossor MN: Regional brain metabolite abnormalities in inherited prion disease and asymptomatic gene carriers demonstrated in vivo by quantitative proton magnetic resonance spectroscopy. Neuroradiology 2006, 48:428-433.

6I. Fagge TJ, Barclay GR, Stove GC, Stove G, Robinson MJ, Head MW, Ironside JW, Turner ML: Application of atomic dielectric resonance spectroscopy for the screening of blood samples from patients with clinical variant and sporadic CJD. J Transl Med 2007, 5:4I.

62. Beekes M, Lasch P, Naumann D: Analytical applications of Fourier transform-infrared (FT-IR) spectroscopy in microbiology and prion research. Vet Microbiol 2007, I23:305-3। 9.

63. Piubelli C, Fiorini M, Zanusso G, Milli A, Fasoli E, Monaco S., Righetti PG: Searching for markers of Creutzfeldt-Jakob disease in cerebrospinal fluid by two-dimensional mapping. Proteomics 2006, 6(Suppl I):S256-26I

64. Arlt S, Kontush A, Zerr I, Buhmann C, Jacobi C, Schröter A, Poser S, Beisiegel U: Increased lipid peroxidation in cerebrospinal fluid and plasma from patients with Creutzfeldt-Jakob disease. Neurobiol Dis 2002, 10:150-156.

65. Zerr I, Helmhold M, Poser S, Armstrong VW, Weber T: Apolipoprotein $\mathrm{E}$ phenotype frequency and cerebrospinal fluid concentration are not associated with Creutzfeldt-Jakob disease. Arch Neurol 1996, 53:1233-1238.

66. Choe LH, Green A, Knight RS, Thompson EJ, Lee KH: Apolipoprotein $E$ and other cerebrospinal fluid proteins differentiate ante mortem variant Creutzfeldt-jakob disease from ante mortem sporadic Creutzfeldt-Jakob disease. Electrophoresis 2002, 23:2242-2246.

67. Völkel D, Zimmermann K, Zerr I, Lindner T, Bodemer M, Poser S, Schwarz HP: C-reactive protein and IL-6: new marker proteins for the diagnosis of CJD in plasma? Transfusion 200I, 4I: I509-I5I4.

68. Sanchez IC, Guillaume E, Lescuyer P, Allard L, Carrette O, Scherl A Burgess J, Corthals GL, Burkhard PR, Hochstrasser DF: Cystatin C as a potential cerebrospinal fluid marker for the diagnosis of Creutzfeldt-Jakob disease. Proteomics 2004, 4:2229-2233.

69. Cepek L, Brechlin P, Steinacker P, Mollenhauer B, Klingebiel E, Bib M, Kretzschmar HA, Wiltfang J, Otto M: Proteomic analysis of the cerebrospinal fluid of patients with Creutzfeldt-Jakob disease. Dement Geriatr Cogn Disord 2007, 23:22-28.

70. Sharief MK, Green A, Dick JP, Gawler J, Thompson EJ: Heightened intrathecal release of proinflammatory cytokines in Creutzfeldt-Jakob disease. Neurology 1999, 52:1289-1291.

7I. Stoeck K, Bodemer M, Zerr I: Pro- and anti-inflammatory cytokines in the CSF of patients with Creutzfeldt-Jakob disease. J Neuroimmunol 2006, I72: I75-I8I.

72. Awerbuch G, Peterson P, Sandyk R: Elevated cerebrospinal fluid lactic acid levels in Creutzfeldt-Jakob disease. Int J Neurosci 1988, 42: $1-5$.

73. Bleich S, Kropp S, Degner D, Zerr I, Pilz J, Gleiter CH, Otto M Rüther E, Kretzschmar HA, Wiltfang J, Kornhuber J, Poser S: Creutzfeldt-Jakob disease and oxidative stress. Acta Neurol Scand 2000, I0I:332-334. 